\title{
Antifungal Activity of Chinese Caterpillar Fungus (Ophiocordyceps sinensis Berk.) against Anthracnose Disease on Banana
}

\author{
I. Arumuka Pravin ${ }^{1}$, D. Durgadevi ${ }^{2}$, S. Srivignesh ${ }^{2}$, K. S. Subramanian ${ }^{2}$, \\ S. Nakkeeran ${ }^{1}$, D. Amirtham ${ }^{3}$ and A. S. Krishnamoorthy ${ }^{1^{*}}$ \\ ${ }^{1}$ Department of Plant Pathology, Centre for Plant Protection Studies, \\ TNAU, Coimbatore, India \\ ${ }^{2}$ Department of Nano Science and Technology, Directorate of Natural Resource Management, \\ TNAU, Coimbatore, India \\ ${ }^{3}$ Department of Food \& Agricultural Processing Engineering, AEC\&RI, TNAU, \\ Coimbatore, India \\ *Corresponding author
}

\section{A B S T R A C T}

Keywords

C. musae, Postharvest disease, $O$. sinensis and Mycomolecules

Article Info

Accepted:

05 February 2020

Available Online:

10 March 2020
Tamilnadu is one of the leading banana grower in the country. Eighty-two per cent of fruit production in India is shared by the banana. Banana fruits after harvest are infected by a series of post-harvest pathogens. Among them, anthracnose disease caused by the pathogen Colletotrichum musae is the very dexterous disease. It may cause fruit loss up to 80 per cent. Many fungicides are used to control this disease. The method of applications like dipping, spraying and top dressing is commonly practised. An alternate approach of the application of biological control agents to manage the pathogens is now come into the light. This present study was done to put forth the effect of antifungal activity of a potential biocontrol agent Ophiocordyceps sinensis and its mycomolecules against the post-harvest pathogen $C$. musae.

\section{Introduction}

In India, the southernmost state, Tamil Nadu account the 10 per cent of fruit production of India. The major fruit crops in Tamil Nadu is banana (Musa spp. Family: Musaceae) and mango (Mangifera indica L. Family:
Anacardiaceae). In Tamil Nadu, banana occupies 82 thousand hectares with the production of 32.05 lakh metric tonnes. The districts like Erode, Thoothukudi, Dindigul, Coimbatore and Kanyakumari are leading the banana cultivation and production (Department of Horticulture and Plantation 
Crops, 2019). Post-harvest losses in India is secularly about 20-30 per cent of its annual production (Ahmed and Palta, 2016; Chen et al., 2017). Post-harvest losses due to the invasion of fungal pathogens are leads to the major economic loss and makes the fruit unavailable for consuming. In banana, the anthracnose disease causing pathogen is quiescent in nature and causes latent infection during immature fruits and produces black to brown spots with orange colour acervuli on the central portion of the spot (Krauss et al., 1998; Cordeiro et al., 2005; Sivakumar and Bautista-Baños, 2014; Zhimo et al., 2016, Caroline Lopes Damasceno et al., 2019). Post-harvest diseases can be controlled by use of fungicides as sprays or dips, incorporated in wax or impregnated in packaging materials. Alternative methods to reduce the usage of chemical fungicides like heat treatment (Lurie, 1998), ozone treatment (Kim et al., 1999) and biocontrol agents (Wisniewski and Wilson 1992). The interest of usage of natural volatiles produced from the plants, botanicals and mycomolecules from fungi has also increases markedly (El-Ramady et al., 2015; Mahajan et al., 2014; Song et al., 2007). Ophiocordyceps sinensis (syn: Cordycepssinensis (Berk.) Sacc. Family: Ophiocordycepitaceae, Phylum: Ascomycota), commonly called as "Chinese caterpillar fungus" (Sung et al., 2007), is one of the most valued mushroom fungus in pharmaceutical industry for its antioxidant and anti-inflammatory properties. This fungus can know to parasitize the larvae of the ghost moth (Pegler et al., 1994; Wang, 1995 and Yao, 2004).

The report says that the perfect stage of this mushroom is Beauveria, Metarhizium and Paecilomyces. Exploration of the mycomolecules which are collectively produced by this fungus can able to control the soil borne pathogens, nematodes as well as the harmful insect (Yue et al., 2013).

\section{Materials and Methods}

\section{Collection and maintenance of fungal cultures}

Virulent isolates of banana post-harvest disease anthracnose caused by $C$. musae MT071509 was collected from the stock culture maintained at Department of Plant pathology, TNAU. Slant culture of $O$. sinensis was collected from Mushroom Research and Training Centre, Department of Plant Pathology, TNAU, Coimbatore.

All the collected isolates were subculture in potato dextrose agar medium (PDA) by following the standard procedure. Pure culture of each microbial isolates was maintained under the refrigerated condition at Department of Nano Science and Technology.

\section{Pathogenicity}

Spore suspension of $C$. musae was prepared by using the well sporulation 15 days old culture plate. The culture plate was flushed with sterile distilled water and scrapeed by the sterile brush.

The spore collected was examined under the microscope to standardise the spore population as $10^{4}$ conidia per $\mathrm{ml}$ of water. Then the conidial suspension is added with 0.05 per cent Tween 20 .

The spore suspension of $C$. musae was inoculated to the mid-portion of the banana fingers harvested at 80 per cent maturity from the orchard, TNAU. The spore suspension was inoculated with minor pinprick with sterile needle and inoculated without pinprick. Uninoculated fruits were kept as control. Three replications were maintained and the pathogens were re-isolated from the disease symptom expressing on fruits to confirm Koch's postulates. 
Antifungal activity of $O$. sinensis against $C$. musae

Antifungal activity of $O$. sinensis was tested against the post-harvest pathogens Colletotrichum musae through dual plate technique. A mycelial disc of pathogen was placed on the side of Petri plate, one $\mathrm{cm}$ away from the margin. On the opposite side a mycelial disc of $O$. sinensis was also placed one $\mathrm{cm}$ away from the margin of the Petri plate. The experiment was replicated thrice and the plates were kept at incubation under room temperature $\left(28 \pm 2{ }^{\circ} \mathrm{C}\right)$. Ten days after incubation, inhibition zone and per cent inhibition (PI) of mycelial growth of pathogens were recorded using the formula

$$
\mathrm{PI}=\frac{\mathrm{C}-\mathrm{T}}{\mathrm{C}} \times 100
$$

Whereas,

$\mathrm{C}=$ mycelial growth of pathogen in control plate (without $O$. sinensis)

$\mathrm{T}=$ mycelial growth of pathogen in treated plate (with $O$. sinensis)

Extraction of mycomolecules from $O$. sinensis

Actively grown mycelium of was inoculated in $\mathrm{MC}$ broth ( $\mathrm{pH}$ adjusted to 5.5) and incubated in orbital shaker (Obitek, India) at $25^{\circ} \mathrm{C}$ for 20 days at continuous shaking at 150 rpm (Akshaya, 2016). After 20 days of incubation, the culture was homogenised and centrifuge at 10,000 rpm for 10 minutes. The supernatant was collected to the fresh conical flask and the pellet containing cellular debris and mycelium was discarded. Equal volume of ethyl acetate was added to the supernatant and incubates overnight at orbital shaker at $25^{\circ} \mathrm{C}$ with $150 \mathrm{rpm}$. The fractionate solution was separated using the separating funnel and the upper phase was collected. The collected fraction was subjected for condensation in vacuum flash evaporator at $50^{\circ} \mathrm{C}$ boiling temperature; $150 \mathrm{rpm} ; 400$ psi vacuum pressure. The condensate was collected in the Petri plate and dried using desiccator. The dried condensate was scrapped using HPLC grade methanol for further analysis.

\section{Antifungal activity of mycomolecules $O$. sinensis against $C$. musae}

Antifungal activity of mycomolecules extracted from $O$. sinensis was tested against the post-harvest pathogens $C$. musae through agar well diffusion assay. A mycelial disc of pathogen was inoculated on the centre of the Petri plate. $20 \mu \mathrm{L}$ of Mycomolecules of $O$. sinensis at different concentration 1000, 2000, 3000 and $4000 \mathrm{ppm}$ were inoculated in the three well and water as control. The experiment was replicated thrice and the plates were kept at incubation under room temperature $\left(28 \pm 2^{\mathrm{O}} \mathrm{C}\right)$. Ten days after incubation, inhibition zone and per cent inhibition (PI) of mycelial growth of pathogens were recorded using the formula

$$
\mathrm{PI}=\frac{\mathrm{C}-\mathrm{T}}{\mathrm{C}} \times 100
$$

Whereas,

$\mathrm{C}=$ mycelial growth of pathogen in control plate (without $O$. sinensis)

$\mathrm{T}=$ mycelial growth of pathogen in treated plate (with $O$. sinensis)

\section{GC-MS analysis of mycomolecules of $O$. sinensis}

Characterization of biomolecules of $O$. sinensis was done by GC - MS analysis using Thermo Scientific Trace GC Ultra chromatograph system (Thermo Fischer Scientific, Austria) coupled to Thermo Scientific DSQ II quadruple mass 
spectrometer. Mycomolecules of $O$. sinensis was separated using a TG-SQC capillary column (15 $\mathrm{m}$ in length, $0.25 \mathrm{~mm}$ I.D. and $0.25 \mu \mathrm{m}$ film thicknesses). Helium gas was used as a carrier gas with a flow rate of 1.0 $\mathrm{mL} / \mathrm{min}$ and split mode was used with the split flow of $10 \mathrm{~mL}$. The injector temperature was set at $207^{\circ} \mathrm{C}$. The column temperature programs consisted of the following: initial temperature of $50^{\circ} \mathrm{C}$ (held $1 \mathrm{~min}$ ), increased to $150^{\circ} \mathrm{C}$ at a rate of $25^{\circ} \mathrm{C} / \mathrm{min}$. After each injection, the column temperature was increased to $250^{\circ} \mathrm{C}$ and then held for $7.0 \mathrm{~min}$ to remove the residues that were potentially retained in the column. The transfer line temperature and MS source temperature were 265 and $200^{\circ} \mathrm{C}$, respectively. The sample extraction and introduction were fully automated using a Triplus RSH Head Space Autosampler. The volume of syringe used was $2.5 \mathrm{~mL}$ and needle length was $65 \mathrm{~mm}$. The $20 \mathrm{~mL}$ headspace vials were incubated for 1 min in the agitator with temperature $300^{\circ} \mathrm{C}$. Filling and injection speed was maintained at $20 \mathrm{~mL} / \mathrm{min}$. Pre-injection and post-injection flush were given using nitrogen gas to avoid contamination. The time for pre-injection and post-injection flushing was $5 \mathrm{~s}$ and $30 \mathrm{~s}$ respectively.

\section{Results and Discussion}

\section{Morphological characterization of $\boldsymbol{O}$. sinensis and C. musae}

The fungal isolates collected are sub cultured in PDA medium. The cultured organisms show the typical morphological characters for its identifications. The sub-cultured isolate of C. musae MT071509 shows the grey whitish mycelium with slight orange colour which denotes the induction of the production of acervuli (Plate 1a). pure culture of $O$. sinensis shows that the pure milky white mycelium with orange yellow headed raised basidiocarp. This shows that the available culture is typically $O$. sinensis (Plate 1b). When compared the results with the findings of Petre et al., (2009), there is a slight modification in our isolates that yellowish colour of the colony. Cunningham et al., 1950 reveals that the O.sinensis is closely related to that of C. militaris.

\section{Pathogenesis of C. musae}

Anthracnose is the post harvest disease on banana caused by $C$. musae (Chakravarty 1957; Meredith 1960; Jeger et al., 1995; Jones and Slabaugh, 1998). The spore suspension of C. musae $\left(10^{4}\right.$ conidia / $\left.\mathrm{mL}\right)$ was inoculated in the mid portion of the bananavar Grand Naine fruit. The inoculated fruits exhibit the symptoms at 10 days after inoculation. The typical symptoms exhibit the brown to black colour sunken lesion with orange colour acervuli at the centre of the lesion (Plate 2a and $2 b$ ). The spore suspension inoculated fruit with pinprick exhibits the symptoms but the inoculated fruit without pinprick and control fruits doesn't shows any symptoms. The pathogenesis of $C$. musae is also visualised under Scanning electron microscope. It clearly shows that the pathogen can colonise the surface of the banana fruit peel and the inoculated spore becomes viale and germinate in the surface of the fruit (Plate 2C). Jones and Slabaugh (1998) sated that, it doesn't cause infection only on fruits, it also causes infection on bracts, flowers, petioles and leaves of banana plants. Sutton and Waterson (1970), reported that the C. musae can also cause the infection in apple, mango, avocado and guava.

\section{Antifungal activity of $O$. sinensis}

Antifungal activity of $O$. sinensis against $C$. musae was tested by dual plate method. The result shows that, the $O$. sinensis 10 days after inoculation can inhibit the mycelial growth of the pathogen $C$. musae. 
Table.1 List of Compounds Identified in GC-MS Analysis of mycomolecules extracted from $O$. sinensis

\begin{tabular}{|c|c|c|c|}
\hline $\begin{array}{l}\text { S. } \\
\text { No }\end{array}$ & Compound name & $\begin{array}{l}\text { Retention } \\
\text { time }\end{array}$ & Functions \\
\hline 1 & Ethane, 1-chloro-2-nitro- & 3.62 & Anticancer Activity \\
\hline 2 & Silane, triethyl(2-phenylethoxy)- & 1.29 & Hydrosilylation \\
\hline 3 & $\begin{array}{l}\text { 1-Monolinoleoylglycerol } \\
\text { trimethylsilyl ether }\end{array}$ & 0.12 & $\begin{array}{l}\text { Antimicrobial Antioxidant } \\
\text { AntiinflammatoryAntiarthritic } \\
\text { Antiasthma, Diuretic }\end{array}$ \\
\hline 4 & $\begin{array}{l}\text { 9,12,15-Octadecatrienoic acid, 2,3- } \\
\text { bis[(trimethylsilyl)oxy]propyl ester, } \\
\text { (Z,Z,Z)- }\end{array}$ & 0.01 & $\begin{array}{l}\text { Anti-Inflammatory, Hypocholesterolemic } \\
\text { Cancer Preventive, Hepatoprotective, } \\
\text { NematicideInsectifuge, Antihistaminic } \\
\text { Antieczemic, Antiacne, 5-Alpha } \\
\text { Reductase Inhibitor Antiandrogenic, } \\
\text { Antiarthritic, Anticoronary, Insectifuge }\end{array}$ \\
\hline 5 & $\begin{array}{l}\text { 1,8-Dioxa-5-thiaoctane, 8-(9- } \\
\text { borabicyclo[3.3.1]non-9-yl)-3-(9- } \\
\text { borabicyclo[3.3.1]non9-yloxy)-1- } \\
\text { phenyl }\end{array}$ & 0.02 & Reducing Agent \\
\hline 6 & $\begin{array}{l}\text { Quinoline, 1,2-dihydro-2,2,4- } \\
\text { trimethyl- }\end{array}$ & 0.06 & Antioxidant \\
\hline 7 & Phenol, 2,4-bis(1,1-dimethylethyl) & 0.08 & Antifungal Activity \\
\hline 8 & Cucurbitacin B, dihydro- & 0.02 & Anticancer Activity \\
\hline 9 & $\begin{array}{l}\text { 2,5,5,8a-Tetramethyl-4-methylene- } \\
\text { 6,7,8,8a-tetrahydro-4H,5H -chromen- } \\
\text { 4a-yl hydroperoxide }\end{array}$ & 0.13 & \\
\hline 10 & Isocalamendiol & 0.18 & Anticancer Activity \\
\hline 11 & Widdrolhydroxyether & 3.18 & Antimicrobial Activity \\
\hline 12 & $\begin{array}{l}\text { 2-Cyclohexene-1-carboxylic acid, 2- } \\
\text { (7-hydroxy-3-methyl-1,3-octadienyl)- } \\
\text { 1,3-dimethyl-4-oxo-, methyl ester, } \\
\text { [R-[R*,S*-(E,E)]]- }\end{array}$ & 0.02 & \\
\hline 13 & Corymbolone & 0.13 & Antiplasmodial Activity \\
\hline 14 & Hexadecanoic acid, ethyl ester & 0.16 & $\begin{array}{l}\text { Antioxidant Hypocholesterolemic } \\
\text { Nematicide Pesticide Lubricant } \\
\text { Antiandrogenic }\end{array}$ \\
\hline 15 & $\begin{array}{l}\text { 1,9-Dioxacyclohexadeca-4,13-diene- } \\
\text { 2-10-dione, } 7,8,15,16 \text {-tetramethyl }\end{array}$ & 0.62 & Antibacterial \\
\hline 16 & $\begin{array}{l}\text { 1b,4a-Epoxy-2H- } \\
\text { cyclopenta[3,4]cyclopropa[8,9]cyclou } \\
\text { ndec[1 } 1,2-\mathrm{b}] \text { oxiren-5(6H)-one, 7- } \\
\text { (acetyloxy)decahydro-2,9,10- } \\
\text { trihydroxy-3,6,8,8,10a-penta methyl }\end{array}$ & 0.13 & \\
\hline 17 & Phthalic acid, butyl tetradecyl ester & 0.41 & Anhydration Activity \\
\hline
\end{tabular}




\begin{tabular}{|c|c|c|c|}
\hline 18 & $\begin{array}{l}\text { Dasycarpidan-1-methanol, acetate } \\
\text { (ester) }\end{array}$ & 0.26 & Antifungal, Anticancer, Antiinflammatory \\
\hline 19 & $\begin{array}{l}\text { 7,9-Di-tert-butyl-1-oxaspiro(4,5)deca- } \\
6,9 \text {-diene-2,8-dione }\end{array}$ & 0.48 & \\
\hline 20 & Palmitoleic acid & 1.31 & Ant Antitumor, Anti-Inflammatory \\
\hline 21 & n-Hexadecanoic acid & 12.05 & $\begin{array}{l}\text { Antioxidant Hypocholesterolemic } \\
\text { Nematicide Pesticide Lubricant } \\
\text { AntiandrogenicFlavorHemolytic5-Alpha } \\
\text { Reductase Inhibitor }\end{array}$ \\
\hline 22 & Oleic Acid & 0.16 & Ant Antitumor, Anti-Inflammatory \\
\hline 23 & $\begin{array}{l}\text { Oxiraneundecanoic acid, 3-pentyl-, } \\
\text { methyl ester, trans- }\end{array}$ & 0.02 & \\
\hline 24 & $\begin{array}{l}\text { Dasycarpidan-1-methanol, acetate } \\
\text { (ester) }\end{array}$ & 0.03 & \\
\hline 25 & Oxiraneoctanoic acid, 3-octyl-, cis- & 0.02 & Antiinflamatory \\
\hline 26 & $\begin{array}{l}\text { 10-Acetoxy-2-hydroxy- } \\
\text { 1,2,6a,6b,9,9,12a-heptamethyl-1,3,4, } \\
\text { 5,6,6a,6b,7,8,8a,9,10,11,12,12a,12b,1 } \\
\text { 3,14b-octadecahydro-2 H-picene-4a- } \\
\text { carboxylic acid, methyl ester }\end{array}$ & 0.05 & \\
\hline 27 & $\begin{array}{l}\text { Cholestan-3-one, cyclic 1,2- } \\
\text { ethanediyl aetal, (5á)- }\end{array}$ & 0.18 & Antifungal, Anticancer, Antiinflammatory \\
\hline 28 & $\begin{array}{l}\text { 3',8,8'-Trimethoxy-3-piperidyl-2,2'- } \\
\text { binaphthalene-1,1',4,4'-tet rone }\end{array}$ & 0.55 & Antiinflamatory \\
\hline 29 & 9(11)-Dehydroergosteroltosylate & 2.53 & Fluorescent Property \\
\hline
\end{tabular}

Plate.1a Pure culture of Colletotrichum musae

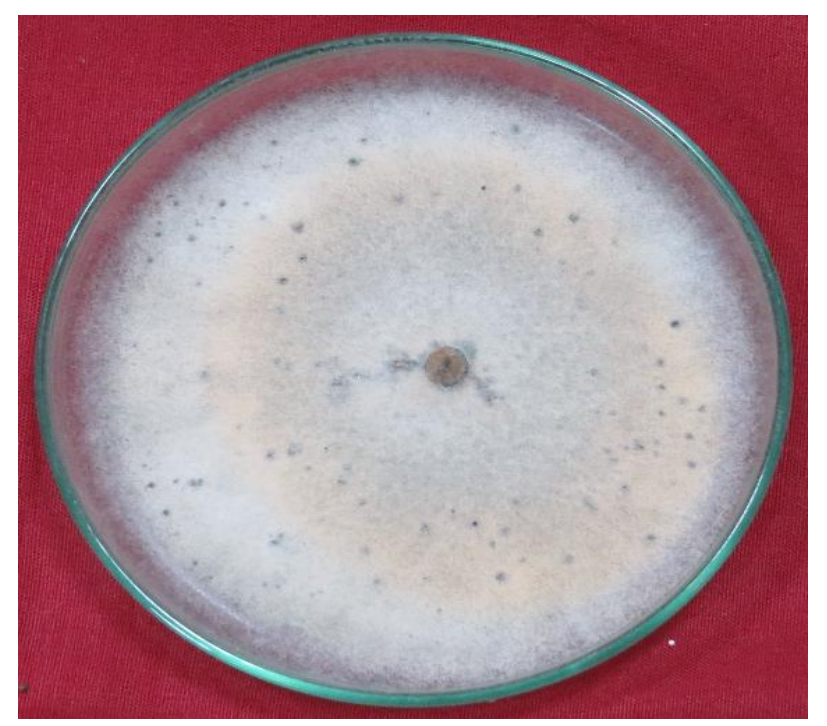


Plate.1b Pure culture of Ophiocordyceps sinensis

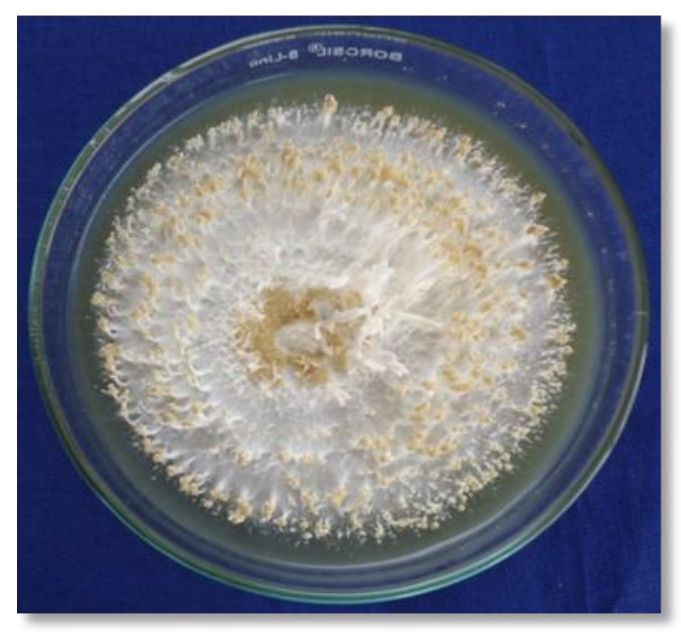

Plate.2a Pathogenesis of C. musae

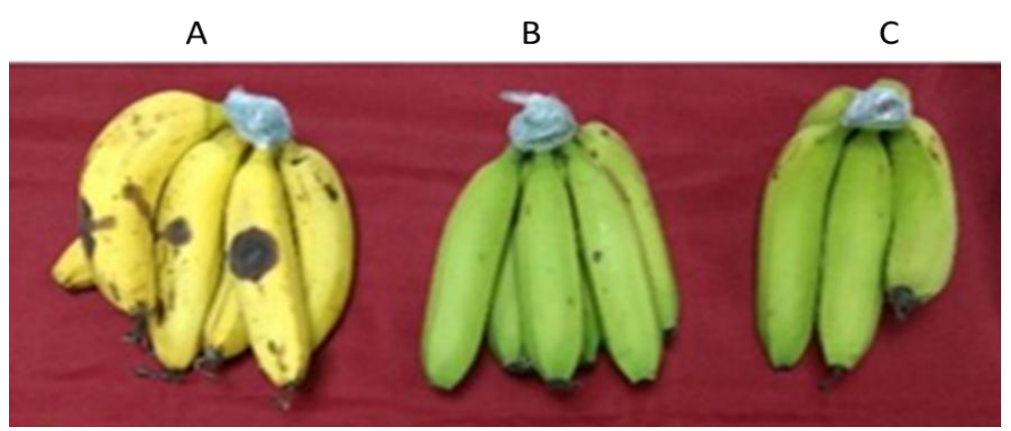

A - Fruits inoculated with C. musae with pinprick B - Fruits inoculated with $C$. musae without pinprick C - Control

Plate.2b SEM image of Pathogenesis of $C$. musae on the epidermis of Banana fruit var. Grand Naine

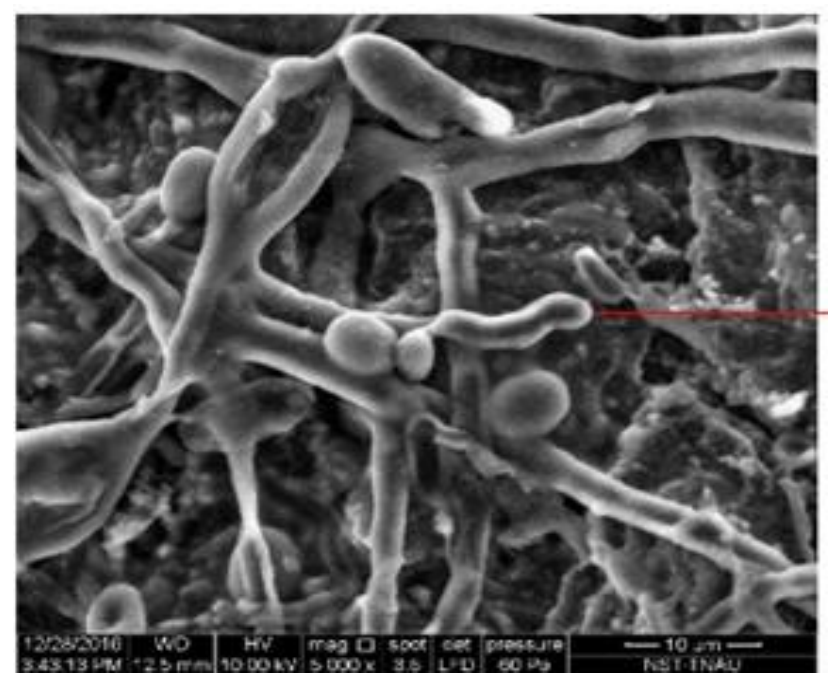


Plate.2c Characteristics symptom of anthracnose produced in Banana var Grand Naine

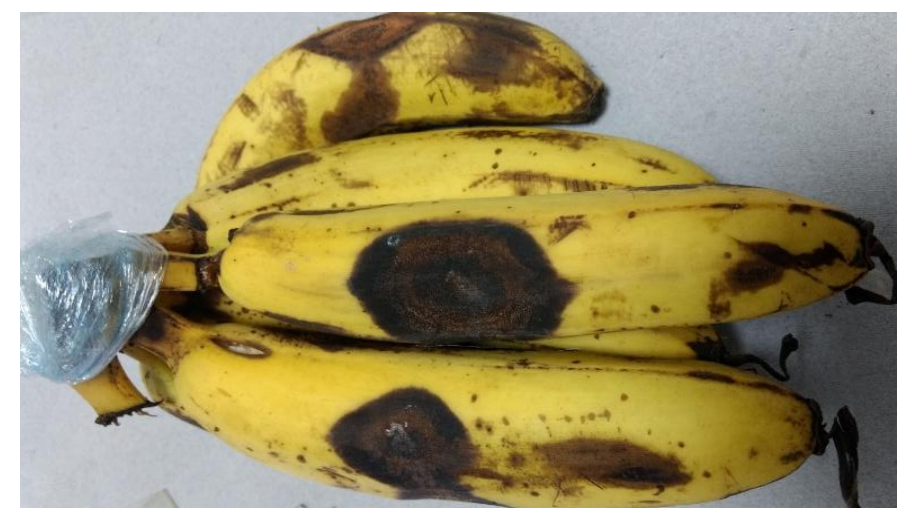

Plate.3 Dual culture technique with $O$. sinensis against $C$. musae

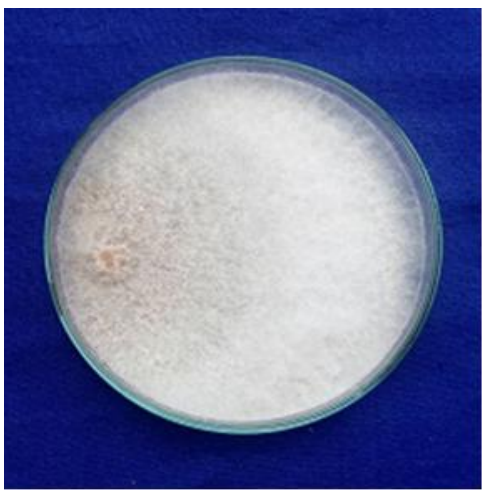

Control

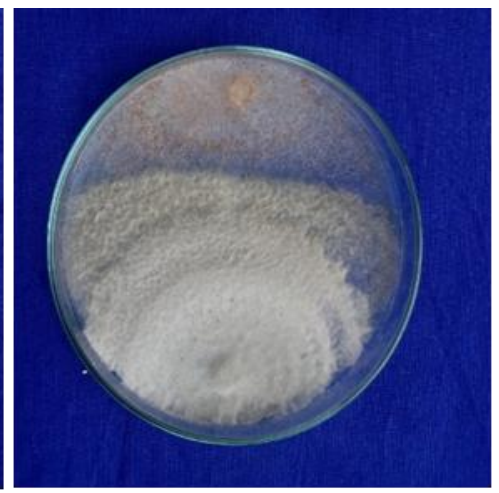

Dual culture with $O$. sinensis

Plate.4 Agar well diffusion test with mycomolecules of $O$. sinensis

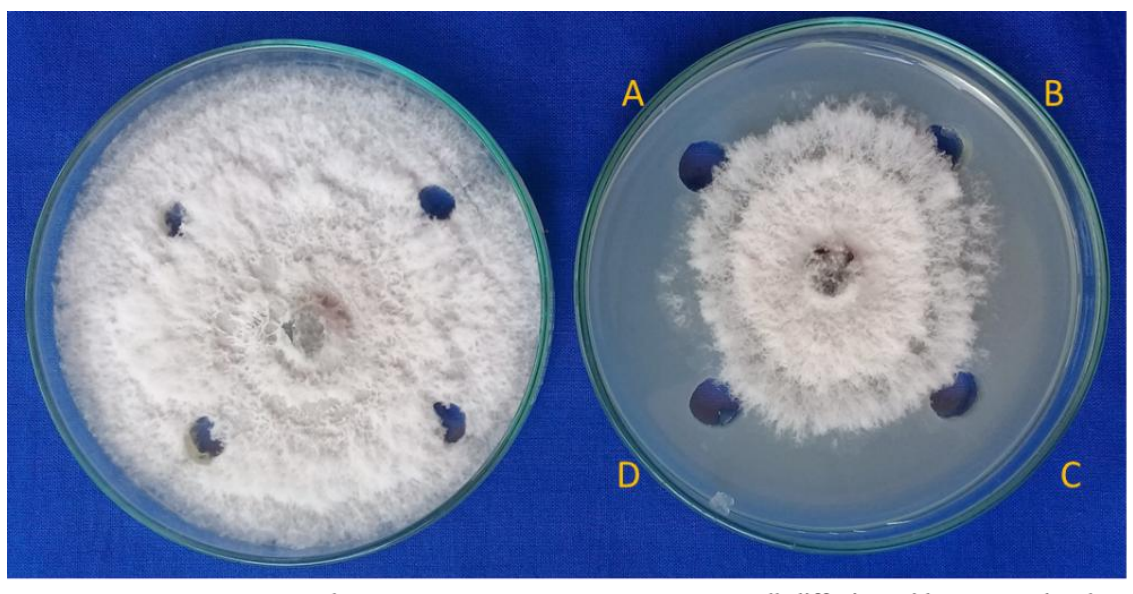

Control

Agar well diffusion with Mycomolecules

A- $1000 \mathrm{ppm}$ of crude mycomolecule

B- $2000 \mathrm{ppm}$ of crude mycomolecule

C- 3000 ppm of crude mycomolecule

D- 4000 ppm of crude mycomolecule 
Figure.1 Antifungal activity against mycelial growth of $C$. musae

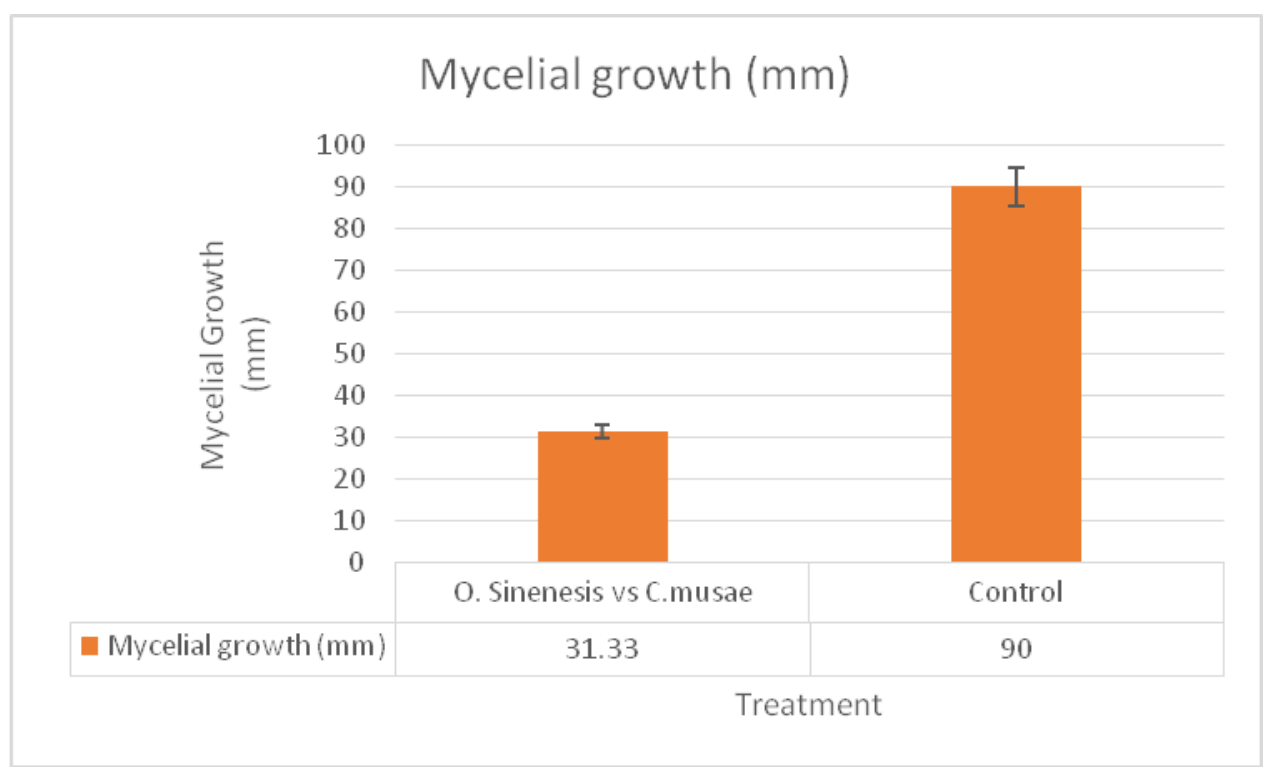

Figure.2 Chromatogram of compounds present in mycomolecules of $O$. sinensis

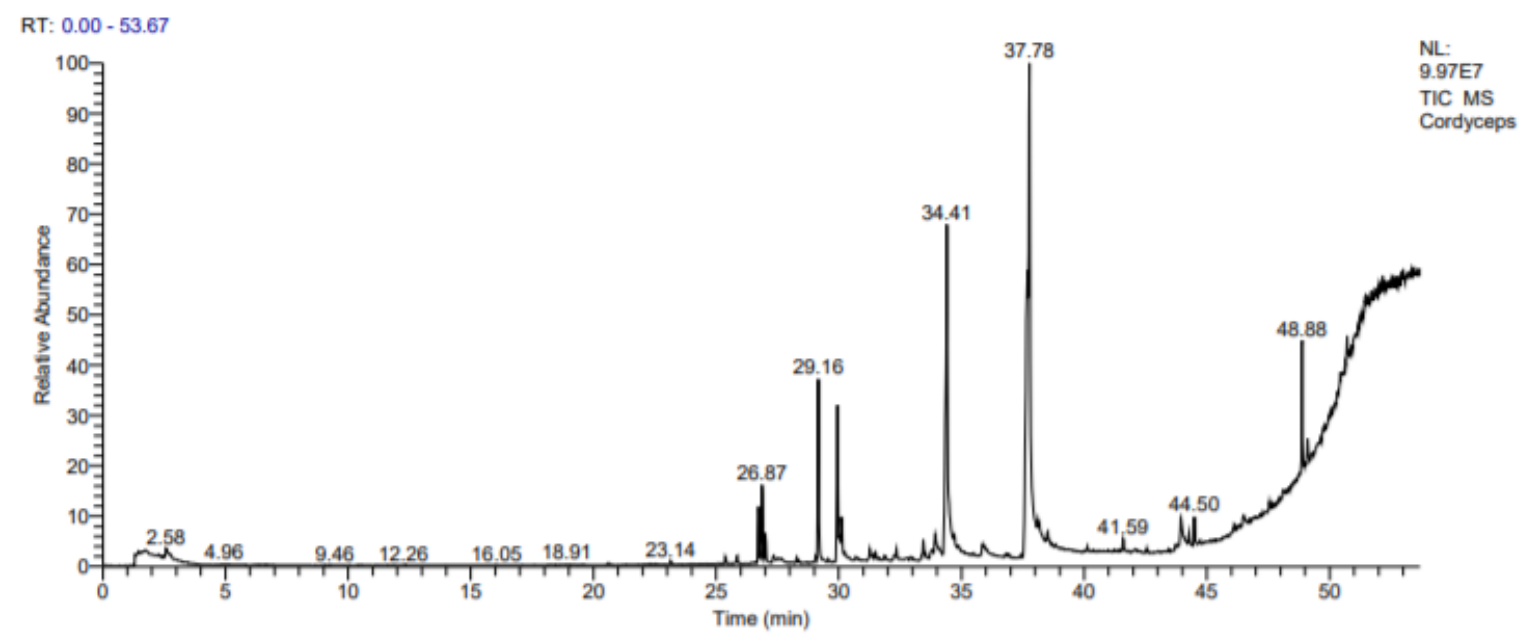

The growth of the biocontrol fungus $O$. sinensis is $56 \mathrm{~mm}$ and the mycelial growth of the pathogen $C$. musae is only $31.33 \mathrm{~cm}$. The inhibition zone recorded is $2 \mathrm{~mm}$. The percent inhibition of the mycelial growth is 65.19 per cent (Figure 1 and Plate 3). Pandey (2010) had observed very strong competitive interaction and inhibition at mycelial contact (37.5 per cent) followed by inhibition and replacement (30.00 per cent) and inhibition at a distance (5 per cent), when $F$. oxysporum and $F$. solani were challenge inoculated with macrofungi like Coprinussp., Pycnoporussp., Cordyceps sp. and Polyporus sp.

\section{Antifungal activity of mycomolecules against $C$. musae}

The mycomolecules extracted from the broth culture of $O$. sinensis was tested against $C$. musae by agar well diffusion method. The results declared that, the overall mycelial 
growth was inhibited when compare to control but there is no clear zone of inhibition formed. The mycelial growth of the pathogen is uniform in all concentrations. At once, the control reaches $90 \mathrm{~mm}$ of mycelial growth, the treated reaches only $7 \mathrm{~cm}$ of growth (Plate 4).

\section{Antifungal compounds present in crude extract of mycomolecules from $O$. sinensis}

The ethyl acetate fraction of mycomolecules from $O$. sinensis is subjected to GC-MS analysis. It is found that the total of 29 compounds is present. Among the 29 compounds, 1-Monolinoleoylglycerol trimethylsilyl ether $(0.12 \%), 9,12,15$ Octadecatrienoic acid, 2,3-bis [(trimethylsilyl) oxy]propyl ester, (Z,Z,Z)- (0.01 ), Phenol, 2,4-bis(1,1-dimethylethyl) (0.08\%), Widdrol hydroxyether (3.18\%), Dasycarpidan-1methanol, acetate (ester) (0.26 \%), nHexadecanoic acid (0.16 \%), 1,9-Dioxacyclohexadeca-4,13-diene-2-10-dione, 7,8,15,16tetramethyl $(0.62 \%)$ and Cholestan-3-one, cyclic 1,2-ethanediyl aetal, (5á)- $(0.18 \%)$ are responsible for the antifungal nature of the mycomolecules (Table 2, Figure 1). A number of bioactive compounds obtained from Cordyceps spp have also been reported to possess multiple pharmacological properties including anti-fungal, antimicrobial, anti-tumor, anti-inflammatory and immunomodulatory activities (Jiang et al., 2002; Schuffler and Anke, 2009; Colombo and Ammirati, 2011; Qian et al., 2012).

\section{References}

Ahmed. Z.F.R. and Palta. J.P. (2016). Postharvest dip treatment with a natural lysophospholipid plus sJoy lecithin extended the shelf life of banana fruit. Postharvest Biol Technol., 113; 58-65

Chakravarty, T. (1957). Anthracnose of banana (Gloeosporium musarumCke.
\&Massee) with special reference to latent infection in storage. Transactions of the British Mycological Society, 40(3), 337-IN1.

Chen, Y., Liao, Y., Lan, Y., Wu, H., and Yanagida, F. (2017). Diversity of Lactic Acid Bacteria Associated with Banana Fruits in Taiwan. Current Microbiology, 74(4), 484-490.

Colombo, D. and Ammirati, E. (2011). Cyclosporine in transplantation- a history of converging timelines. $\mathrm{J}$ Biol Regul Homeost Agents, 25(4): 493-504.

Cordeiro, Z.J.M., Matos, A.P. and Kimati, H. (2005). Doenças da bananeira. In: Kimati, H., Amorim, L., Rezende, J.A.M., BergaminFilho, A., Camargo, L.E.A. (Eds.), Manual de fitopatologia: doenças das plantascultivadas. Agronômica Ceres, São Paulo, pp. 99117.

Cunningham, K. G., Manson, W., Spring, F. S., and Hutchinson, S. A. (1950). Cordycepin, a metabolic product isolated from cultures of Cordyceps militaris (Linn.) Link. Nature, 166(4231), 949-949.

Damasceno, C. L., Duarte, E. A. A., dos Santos, L. B. P. R., de Oliveira, T. A. S., de Jesus, F. N., de Oliveira, L. M. and Soares, A. C. F. (2019). Postharvest biocontrol of anthracnose in bananas by endophytic and soil rhizosphere bacteria associated with sisal (Agave sisalana) in Brazil. Biological Control, 137, 104016.

Department of Plantation Crops (2019). https://nilgiris.nic.in/departments/depart ment-of-horticulture-and-plantationcrops/

Hassan R. El-Ramady, Éva DomokosSzabolcsy, Neama A. Abdalla, Hussein S. Taha and MiklósFári. (2015). Postharvest Management of Fruits and Vegetables Storage. Sustainable Agriculture Reviews, 15: 65-152

Jeger, M. J., Eden-Green, S., Thresh, J. M., 
Johanson, A., Waller, J. M., and Brown, A. E. (1995). Banana diseases. In Bananas and plantains (pp. 317-381). Springer, Dordrecht.

Jiang, Y. and Yao, Y. J. (2002). Names related to Cordyceps sinensis anamorph. Mycotaxon., 4: 245-254.

Jones DR and Slabaugh WR. (1998) Anthracnose and fungal scald. In: Ploetz RC, Zentmyer GA, Nishijima WT, Rohrbach KG, Ohr HD, editors. Compendium of tropical fruit diseases. Minnessota, USA: American Pathological Society Press;. pp. 4-5.

Kim K, Kim K, Kim KH, Storey MK, Voelker DR, and Carman GM (1999) Isolation and characterization of the Saccharomyces cerevisiae EKI1 gene encoding ethanolamine kinase. $J$ BiolChem 274(21):14857-66

Krauss, U., Bidwell, R., Ince, J., 1998. Isolation and preliminary evaluation of mycoparasites as biocontrol agents of crown rot of banana. Biol. Control 13, 111-119.

Lurie, S., 1998. Postharvest heat treatments of horticultural crops. Hortic. Rev. 22, 91121

Mahajan P. V., Caleb O. J., Singh Z., Watkins C. B. and Geyer M. Postharvest treatments of fresh produce 372 Philosophical Transactions of the Royal Society A: Mathematical, Physical and Engineering Sciences http://doi.org/10.1098/rsta.2013.0309

Meredith DS (1960). Studies on Gloeosporium musarumCke. \& Mass. causing storage rots of Jamaican bananas. I. Anthracnose and its chemical control. Ann. Appl. Biol. 48: 279-290.

Pandey A, Mohanty PS, Arya P, and Rathod D (2010) Genetic diversity among the isolates of Cordyceps sinensis of higher Himalayan meadows of India. Int $J$ Sci Nat 1:242-245
Pegler DN, Yao YJ, Li Y. (1994) The Chinese 'Caterpillar Fungus'. Mycologist 8 (1): 3-5

Petre, M., and Teodorescu, A. (2009). Biotechnology for in vitro growing of edible and medicinal mushrooms on wood wastes. Annals of Forest Research, 52(1), 129-136.

Qian, G.M., Pan, G. F. and Guo, J.Y. (2012). Anti-inflammatory and antinociceptive effects of cordymin, a peptide purified from the medicinal mushroom Cordyceps sinensis. Natural Product Research, 26 (24): 2358-2362.

Schuffler, A. and Anke, T. (2009). Secondary metabolites of Basidiomycetes. In: Physiology and Genetics, Selected Basic and Applied Aspects. (eds. Anke $\mathrm{T}$ and Weber D), Springer, NewYork, pp.209-231.

Sivakumar, D. and Bautista-Baños, S. (2014). A review on the use of essential oils for postharvest decay control and maintenance of fruit quality during storage. Crop Prot. 64,7-37.

Song X-J, Huang W, Shi M, Zhu M-Z, and Lin H-X. 2007. A QTL for rice grain width and weight encodes a previously unknown RING-type E3 ubiquitin ligase. Nature Genetics 39, 623-630.

Sung G-H, Sung J-M, Hywel-Jones NL, and Spatafora JW (2007). A multi-gene phylogeny of Clavicipitaceae (Ascomycota, Fungi): Identification of localized incongruence using a combinational bootstrap approach. Molecular Phylogenetics and Evolution, in press.

Sutton, B. C., and Waterston, N. W. (1970). CMI Description of pathogenic fungi and bacteria, No. 222. Commonwealth Mycological Institute, Kew, Surry, England.

Wang GD. (1995) Cordyceps species: ecology, cultivation and application. Science and Technology Reference 
Press, Beijing, 307 pp.

Wisniewski, M., Wilson, C.L., 1992. Biological control of postharvest diseases of fruits and vegetables: recent advances. Hort. Science 27, 94-98.

Yao YJ. (2004) Conservation and rational use of the natural resources of Cordyceps sinensis. Science News (15): 28-29.

Yue, K., Ye, M., Zhou, Z., Sun, W., \& Lin, X. (2013). The genus C ordyceps: a chemical and pharmacological review. Journal of Pharmacy and Pharmacology, 65(4), 474-493.

Zhimo, V.Y., Dilip, D., Sten, J., Ravat, V.K., Bhutia, D.D., Panja, B. and Saha, J. (2016). Antagonistic Yeasts for Biocontrol of the banana postharvest anthracnose pathogen Colletotrichum musae. J. Phytopathol. 165 (1), 35-43.

\section{How to cite this article:}

Arumuka Pravin, I., D. Durgadevi, S. Srivignesh, K. S. Subramanian, S. Nakkeeran, D. Amirtham and Krishnamoorthy, A. S. 2020. Antifungal Activity of Chinese Caterpillar Fungus (Ophiocordyceps sinensis Berk.) against Anthracnose Disease on Banana Int.J.Curr.Microbiol.App.Sci. 9(03): 848-859. doi: https://doi.org/10.20546/ijcmas.2020.903.100 